\title{
SIKAP PEJALAN KAKI TERHADAP SETING RUANG TRANSISI PADA MAL DI SEMARANG
}

\author{
Tri Susetyo Andadari ${ }^{1}$, Djoko Indrosaptono ${ }^{2}$ \\ ${ }^{1}$ Mahasiswa Program Studi Magister Arsitektur, Fakultas Teknik, Universitas Diponegoro, 50275 \\ ${ }^{2}$ Dosen Program Studi Magister Arsitektur, Fakultas Teknik, Universitas Diponegoro, 50275 \\ *andadaritri@gmail.com
}

Diterima: 16-02-2021 Direview : 14-06-2021 Direvisi : 29-06-2021 Disetujui: 15-08-2021

\begin{abstract}
ABSTRAK. Ruang transisi merupakan ruang penyangga atau ruang pengantar atau ruang peralihan atau ruang penghubung menuju ruang utama, yang fungsinya sebagai perekat antar ruang dan memberikan pengantar akan pengalaman meruang berikutnya, serta memberikan jeda kepada pengguna ruang untuk beraktivitas sebelum memasuki ruang utama. Ruang transisi penting sebagai pembentuk persepsi seseorang terhadap ruang selanjutnya, sehingga dalam perancangannya perlu mempertimbangkan sikap perilaku pengguna sebagai dasar mendesain ruangan. Permasalahan utama yang tampak pada ruang transisi pada obyek studi adalah adanya kemacetan pada ruang transisi, akibat bertemunya pejalan kaki dengan kendaraan bermotor yang bisa mempengaruhi kenyamanan pejalan kaki. Penelitian ini berusaha mengetahui dan menjelaskan permasalahan dengan paradigma kuantitatif, dengan cara berfikir deduktif, dengan tipologi pendekatan adalah positivistik, dengan metode analisis statistik deskriptif. Penelitian ini berusaha mengetahui kaitan antara sikap pejalan kaki terhadap seting ruang transisi (ruang antara pagar pintu masuk kawasan sampai dengan pintu masuk utama gedung) pada obyek studi, terkait dengan kenyamanan fisik, kenyamanan sirkulasi dan kenyamanan aksesibilitas. Hasil akhir menunjukkan bahwa adanya kaitan antara sikap pejalan kaki dengan seting ruang transisi terkait atribut kenyamanan fisik, kenyamanan sirkulasi dan kenyamanan aksesibilitas. Indikator kenyamanan yang paling menonjol adalah panas, tidak adanya pembatas bagi pejalan kaki dan kendaraan bermotor, terganggunya pejalan kaki ketika berpapasan dan jarak pencapaian yang tidak efektif.
\end{abstract}

Kata kunci: Sikap, Seting Ruang, Ruang Transisi

ABSTRACT. The transitional space is a buffer room or threshold room or transition room or connecting room to the main room, which has many functions as a connector between spaces and provides an introduction to the experience of the next room and gives an interlude before entering the main room. The transitional space is essential as forming perception of the next space, so it is necessary to consider man behaviour as the basis for designing it. The main problem in the Object study transition room is the congestion due to the meeting of pedestrians with vehicles that can affect the comfort of pedestrians. This research tries to identify and explain the problem with a quantitative paradigm, deductive thinking, with the typology of a positivistic approach, and descriptive statistical analysis methods. This research seeks to determine the relationship between pedestrian attitudes towards the setting of the transition space (the space between the entrance gate to the main entrance of the building) in the object study, especially to physical, circulation, and accessibility convenience. The final result shows a relationship between pedestrian attitudes and the arrangement of the transitional space related to the attributes of physical, circulation, and accessibility comfort. The most prominent indicators of comfort are heat, the absence of barriers for pedestrians and motorized vehicles, disruption of pedestrians when passing, and distances that are ineffective to reach.

Keywords: Attitude, Room Setting, Transitional Space

\section{PENDAHULUAN}

Ruang transisi oleh Boettger diistilahkan sebagai threshold space, merupakan suatu ruang pengantar untuk menuju ke pengalaman spasial yang akan datang. "Spasial" berarti ruang arsitektur, yang ditentukan oleh pengalaman fisik individu dalam gerak dan persepsi (Boettger, 2014). Selain mengacu pada transisi dari satu ruang ke ruang yang lain, istilah ini juga menggabungkan ambivalensi antara bukaan dan penutup ruang (Boettger, 2014).

Sedangkan menurut Subiyantoro, dalam proses mengkomposisikan ruang utama dan ruang penunjang, harus dibuat formulasi yang bagus dengan menyertakan ruang penyangga 
yang dapat merekatkan suatu aliran ruang. Ruang penyangga ruang utama inilah yang kemudian disebut sebagai ruang transisi (Subiyantoro, 2018).

Ruang transisi pada obyek studi ini dijelaskan sebagai ruangan yang menghubungkan ruang luar yang bersifat sebagai ruang publik dan ruang didalam mall yang bersifat sebagai ruang privat, sehingga keberadaannya bisa menjadi ruang semi publik. Terdapat 3 zonasi yang berbeda pada lokasi studi, yaitu selasar tertutup setelah anak tangga sampai ruang entrance pada pintu masuk utama mall, anak tangga dan selasar terbuka setelah pagar main entry kawasan obyek studi.

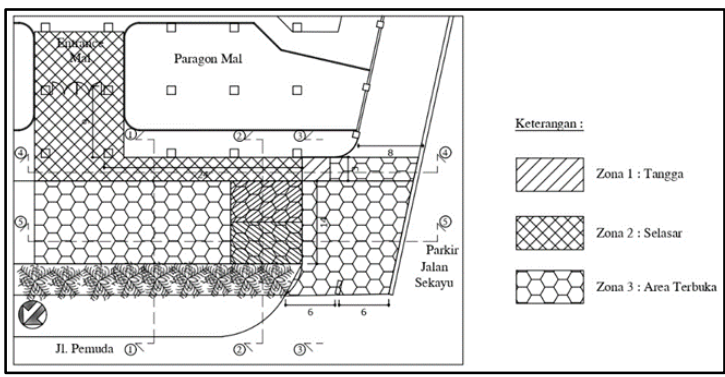

Gambar 1 Pembagian Zonasi Wilayah Penelitian Sumber: Analisa Pribadi, 2020

Permasalahan utama yang tampak pada ruang transisi obyek studi adalah bercampurnya pejalan kaki dengan kendaraan bermotor sehingga saling bertabrakan baik antar pejalan kaki maupun pejalan kaki dengan kendaraan. Berdasarkan kondisi tersebut, maka rumusan masalah untuk penelitian ini adalah apakah ada kaitannya antara sikap pejalan kaki terhadap seting ruang transisi obyek studi terkait dengan atribut kenyamanan pejalan kaki.

"Sikap adalah salah satu istilah bidang psikologi yang berhubungan dengan persepsi dan tingkah laku" (Suharyat, 2009). Selain sikap, faktor dari dalam diri yang membentuk persepsi antara lain adalah, motif, minat, pengalaman dan harapan (Wijaya, 2017). Marleni mengungkapkan bahwa "minat seseorang terhadap suatu objek akan lebih kelihatan apabila objek tersebut sesuai sasaran (tujuan) dan berkaitan dengan keinginan (rasa) dan kebutuhan seseorang yang bersangkutan" (Sudirman Dalam Marleni, 2016). Slameto menyatakan bahwa minat sebagai suatu rasa lebih suka dan rasa keterikatan pada suatu hal atau aktivitas, tanpa ada yang menyuruh (Slameto, 2003). Sikap memiliki hubungan dengan aspek motivasi dan perasaan atau emosi (Suharyat,
2009). Menurut Moeldiono "Minat adalah kecederungan hati yang tinggi terhadap sesuatu" (Moeliono, 1989). "Motif merupakan sesuatu yang melingkupi semua penggerak, alasan atau dorongan yang menyebabkan ia berbuat sesuatu" (Handayani \& Laugu, 2007). Berdasarkan pada teori Woodwort dalam Gerungan terdapat beberapa kemungkinan fenomena yang terjadi yang bisa menafsirkan motiv seseorang yaitu (1)Pelaku menentang lingkungan, (2)Pelaku ikut serta/memanfaatkan lingkungan dan (3)Pelaku pergi dari lingkungan (Gerungan, 2000). Harapan adalah sesuatu yang diinginkan untuk menjadi nyata.

Dalam penelitian ini, pengertian sikap hanya dibatasi pada sikap pejalan kaki yang berkaitan dengan kenyamanan fisik, kenyamanan sirkulasi dan kenyamanan aksesibilitas pejalan kaki terhadap seting ruang transisi obyek studi.

Kenyamanan (comfort) diartikan sebagai kondisi lingkungan yang memberi rasa nyaman yang sesuai dengan tuntutan panca indera dan antropometrik (menyangkung proporsi, dimensi dan karakteristik fisiologis), serta rasa mampu memfasilitasi kegiatan untuk mendapatkan produktivitas dan efisiensi kerja yang berarti suatu penghematan dalam penggunaan ruang. Selain dari kenyamanan fisik yang merupakan respon dari panca indera, kenyamanan juga mencakup terpenuhinya pengguna properti akan beberapa hal, diantaranya adalah kenyamanan sirkulasi dan kenyamanan aksesibilitas masing-masing individu. Kenyamanan sirkulasi berkaitan dengan kelancaran pergerakan pengguna dari suatu tempat menuju ketempat lainnya. Disamping itu kenyamanan sirkulasi menyangkut juga tentang kemudahan yang berhubungan dengan kejelasan signage untuk memperlancar pergerakan pengguna. Menurut Hakim, signage sebagai elemen dasar sirkulasi berfungsi sebagai alat komunikasi antar manusia dalam suatu bangunan atau lingkungan mengandung beberapa elemen penting (Hakim, 2003). Diantaranya adalah teks, warna, symbol, panah dan pencahayaan. Kenyamanan aksesibilitas adalah kemudahan untuk bergerak dalam rangka melalui atau menggunakan lingkungan. Kemudahan disini mencakup aspek kelancaran sirkulasi dalam arti tidak menyulitkan pemakai dan tidak membahayakan pemakai (Wiesmann, 1981).

Dalam hubungannya dengan perilaku manusia, Atkinson menyatakan bahwa kondisi lingkungan (setting) akan membentuk sikap 
perilaku manusia, dan sebaliknya sikap perilaku manusia akan membentuk lingkungannya. Hal ini disebabkan karena perilaku manusia adalah hasil interaksi secara terus menerus antara variabel pribadi dengan variabel lingkungan (Atkinson, 1983).

Lao Tzu mengemukakan bahwa ruang transisi adalah salah satu hierarki rudang yang merupakan ruang peralihan yang membentuk suatu hubungan antara dunia di dalam dan dunia di luar, (Surasetja, 2007). Sedangkan menurut Schulz \& Christiani, ruang transisi merupakan properti dasar keberadaan manusia (Norberg-Schulz, 1971) (Utami et al., 2018). Pada area public setting, transisi dapat bervariasi dalam skalanya yang kemudian hal tersebut berhasil menciptakan ruang luar yang elastis (Singh, 2015). Ruang transisi bisa juga dipandang sebagai tempat yang memiliki kontrol atas privasi, gerakan serta mencakup perlindungan ruang dari pandangan luar (Asadi, 2015). Kondisi tersebut berkaitan dengan maknanya sebagai proses perubahan dari satu kondisi ke kondisi yang lain, di mana terletak di antara 'ruang luar' dan 'ruang dalam' pada suatu lingkungan, sekaligus bertindak sebagai ruang penyangga maupun penghubung secara fisik, selain berfungsi sebagai rute sirkulasi bagi bangunan (Nassar, 2014).

\section{METODE PENELITIAN}

Penelitian ini berusaha mengetahui dan menjelaskan permasalahan dengan paradigma kuantitatif, dengan cara berfikir deduktif, dengan tipologi pendekatan adalah positivistik. Selain itu penelitian ini bertujuan untuk mengetahui kaitan antara dua variabel, yang terdiri dari variabel independen (variabel yang mempengaruhi) dan dependen (variabel yang dipengaruhi). Type hubungan antar variable penelitian yang dipakai dalam penelitian ini adalah type hubungan searah (tidak timbal balik).

Pada sebuah penelitian kuantitatif sampel benar-benar boleh dilaksanakan apabila keadaan subjek didalam populasi benar-benar homogen, sehingga dapat mewakili populasinya (Arikunto, 2003). Dalam penelitian ini yang dijadikan sebagai sampel adalah pejalan kaki pejalan kaki pada ruang transisi yang memiliki sifat homogen.

Dan untuk pemilihan sampel dilakukan dengan cara random, yaitu teknik pengambilan sampel dimana semua individu dalam populasi baik secara sendiri-sendiri atau bersama-sama diberi kesempatan yang sama untuk dipilih sebagai anggota sampel, (Sugiyono, 2012). Jumlah responden ditentukan sebanyak 40 orang dengan mempertimbangkan prinsip keterbatasan waktu, biaya dan tenaga, dilakukan sesuai waktu kegiatan (Singarimbun, 1992). Namun tetap sesuai dengan ketentuan untuk ukuran sampel yang layak dalam penelitian yaitu antara 30 sampai dengan 500 responden (Sugiyono, 2012).

Metode penggalian data diambil dari data hasil survey lapangan, data-data hasil kajian literatur dan pembagian kuesioner kepada responden. Hasil data diolah dengan menggunakan excel untuk mendapatkan nilai rata-rata. Metode analisis data yang digunakan dalam penelitian ini adalah analisis statistik deskriptif. Analisis statistik deskriptif adalah penelitian yang menggambarkan keadaan data apa adanya, dengan menggunakan parameter tertentu. Hasil olah data dengan nilai kecenderungan tertinggi (diatas mean) didiskripsikan dengan realitas seting lapangan yang ada.

Dalam penelitian ini, terdapat dua variabel yang digunakan, yaitu variabel bebas dan variabel terikat. Variabel bebas juga disebut dengan variabel stimulus, variabel prediktor, variabel antecedent, variabel eksogen, merupakan variabel yang menjadi sebab hadirnya atau timbulnya variabel terikat. Variabel terikat juga disebut variabel output, variabel kriteria, variabel konsekuen, variabel endogen, merupakan variabel yang dipengaruhi atau yang menjadi akibat dari adanya variabel bebas. Tabulasi variable bebas dan terikat yang digunakan pada penlitian ini, bisa dilihat pada table 1 dan 2 . 
Tabel 1 Indikator dan tolok Ukur Variabel bebas

\begin{tabular}{|c|c|c|c|c|c|c|c|c|}
\hline Variabel Bebas & Indikator Sikap & \multicolumn{4}{|c|}{ Tolok Ukur } & Indikator Atribut & Sub Indikator & Tolok Ukur \\
\hline \multirow{16}{*}{$\begin{array}{l}\text { Persepsi } \\
\text { Pembentuk } \\
\text { Sikap dan } \\
\text { Atribut } \\
\text { Kenyamanan }\end{array}$} & \multirow{6}{*}{ Motiv } & \multirow[t]{3}{*}{1} & \multirow{3}{*}{\multicolumn{3}{|c|}{ Pejalan kaki memilih melewati tangga }} & \multirow{6}{*}{$\begin{array}{l}\text { Kenyamanan } \\
\text { Fisisk }\end{array}$} & \multirow{2}{*}{$\begin{array}{l}\text { Indra peraba } \\
\text { rasa }\end{array}$} & 1. Panas \\
\hline & & & & & & & & 2. Teduh \\
\hline & & & & & & & Indra & 1. Kontrol suasana \\
\hline & & \multirow[t]{3}{*}{2} & \multirow{3}{*}{\multicolumn{3}{|c|}{ Pejalan kaki memilih tidak melewati tangga }} & & penglihatan & 2. Butuh konsentrasi \\
\hline & & & & & & & Visibilitas & 1. Terhalangi \\
\hline & & & & & & & & 2. Bebas pandangan \\
\hline & \multirow[t]{4}{*}{ Harapan } & \multirow[t]{2}{*}{1} & \multirow{2}{*}{\multicolumn{3}{|c|}{$\begin{array}{l}\text { Area untuk berjalan kaki di ubah } \\
\text { (adjustment) }\end{array}$}} & \multirow{4}{*}{$\begin{array}{l}\text { Kenyamanan } \\
\text { Sirkulasi }\end{array}$} & Sirkulasi & 1. Batas ruang pejalan kaki jelas \\
\hline & & & & & & & & $\begin{array}{l}\text { 2. Tidak ada batas antara pejalan } \\
\text { kaki dan kendaraan }\end{array}$ \\
\hline & & \multirow[t]{2}{*}{2} & \multirow{2}{*}{\multicolumn{3}{|c|}{$\begin{array}{l}\text { Area untuk berjalan kaki di biarkan apa } \\
\text { adanya (adaptasi) }\end{array}$}} & & \multirow{2}{*}{ Signage } & $\begin{array}{l}\text { 1. Lancar karena Terdapat tanda } \\
\text { pengarah }\end{array}$ \\
\hline & & & & & & & & pengarah tertutup \\
\hline & \multirow[t]{6}{*}{ Minat } & \multirow{2}{*}{\multicolumn{2}{|c|}{ Tujuan minat }} & \multirow{2}{*}{\multicolumn{2}{|c|}{ Rasa minat }} & \multirow{2}{*}{$\begin{array}{l}\text { Kenyamanan } \\
\text { Aksesibilitas }\end{array}$} & \multirow{2}{*}{\begin{tabular}{|l|} 
Jarak \\
pencapaian
\end{tabular}} & 1. Jauh (ada hambatan) \\
\hline & & & & & & & & 2. Dekat (tanpa halangan) \\
\hline & & \multirow[t]{2}{*}{1} & \multirow[t]{2}{*}{$\begin{array}{l}\text { Segera sampai } \\
\text { ke pintu masuk } \\
\text { utama }\end{array}$} & \multirow[t]{2}{*}{1} & \multirow[t]{2}{*}{$\begin{array}{l}\text { Aman terhadap } \\
\text { kendaraan }\end{array}$} & & \multirow[t]{2}{*}{ Kelancaran } & $\begin{array}{l}\text { 1. Mudah dicapai (ketika } \\
\text { berpapasan pembicaraan tidak } \\
\text { terputus) }\end{array}$ \\
\hline & & & & & & & & $\begin{array}{l}\text { 2. Sulit dicapai (ketika berpapasan, } \\
\text { pembicaraan terputus) }\end{array}$ \\
\hline & & \multirow[t]{2}{*}{2} & \multirow[t]{2}{*}{$\begin{array}{l}\text { Dapat berjalan } \\
\text { biasa }\end{array}$} & \multirow[t]{2}{*}{2} & \multirow[t]{2}{*}{$\begin{array}{l}\text { Tidak bersinggunan } \\
\text { antar pejalan kaki }\end{array}$} & & \multirow[t]{2}{*}{ Kemudahan } & $\begin{array}{l}\text { 1. Harus Berhenti ketika membawa } \\
\text { belanjaan }\end{array}$ \\
\hline & & & & & & & & $\begin{array}{l}\text { 2. Berjalan biasa ketika membawa } \\
\text { belanjaan }\end{array}$ \\
\hline
\end{tabular}

Sumber: Dikembangkan dari (Indrosaptono, 2011)

Tabel 2 Seting Ruang Transisi Sebagai Variabel terikat

\begin{tabular}{|c|c|c|c|c|}
\hline No & Item & Zona 1 Area Tangga & Zona 2 Area Selasar & Zona 3 area terbuka \\
\hline 1 & $\begin{array}{l}\text { Bentuk } \\
\text { desain }\end{array}$ & $\begin{array}{l}\text { Terdapat } 11 \text { anak tangga. Bagian } \\
\text { atap tertutup, tapi bagian dindingnya } \\
\text { hanya tertutup pada } 1 \text { sisi saja }\end{array}$ & $\begin{array}{l}\text { Berupa selasar datar. Bagian atap } \\
\text { tertutup }\end{array}$ & $\begin{array}{l}\text { Merupakan area terbuka tanpa } \\
\text { penutup atap, kondisi ada yang } \\
\text { datar dan miring, tidak terdapat } \\
\text { pembatas antara pejalan kaki } \\
\text { dengan kendaraan bermotor }\end{array}$ \\
\hline 2 & Ukuran & $\begin{array}{l}\text { Lebar tangga } 3 \mathrm{~m} \text {, tinggi anak } \\
\text { tangga } 150 \mathrm{~mm} \text { lebar anak tangga } \\
400 \mathrm{~mm}\end{array}$ & $\begin{array}{l}\text { Lebar selasar } 3 \mathrm{~m} \text {, panjang } 24 \mathrm{~m} \text {, } \\
\text { dan pada ujungnya terdapat } \\
\text { ruangan berukuran } 9 \times 9 \mathrm{~m}\end{array}$ & $\begin{array}{l}\text { Panjang dari pintu masuk } \\
\text { sekitar } 24 \mathrm{~m}\end{array}$ \\
\hline 3 & Warna & $\begin{array}{l}\text { Lantai anak tangga berwarna } \\
\text { orange muda, dinding dicat warna } \\
\text { orange muda, kolom warna crem, } \\
\text { plafond crem }\end{array}$ & $\begin{array}{l}\text { Lantai anak tangga berwarna } \\
\text { crem, kolom warna crem, plafond } \\
\text { warna crem }\end{array}$ & Lantai warna abu \\
\hline 4 & Bahan & $\begin{array}{l}\text { Lantai dari marmer, dinding } \\
\text { pasangan batu bata diplester dan } \\
\text { dicat, dinding penyekat dari kaca } \\
\text { clear dengan penyangga dari } \\
\text { stainless, plafond atas dari ACP }\end{array}$ & $\begin{array}{l}\text { Lantai dari marmer, kolom dari } \\
\text { marmer, plafond atas dari ACP }\end{array}$ & $\begin{array}{l}\text { Material jalan aspal dan cor } \\
\text { beton }\end{array}$ \\
\hline 5 & Tekstur & $\begin{array}{l}\text { Lantai agak kasar, dinding, kaca } \\
\text { penyekat, metal penyangga dan } \\
\text { plafond halus }\end{array}$ & $\begin{array}{l}\text { Lantai halus, kolom halus dan } \\
\text { plafond halus }\end{array}$ & Tektur lantai kasar \\
\hline 6 & Kondisi & Layak digunakan, terawat & Layak digunakan, terawat & Layak digunakan, terawat \\
\hline 7 & $\begin{array}{l}\text { Keleng } \\
\text { kapan }\end{array}$ & $\begin{array}{l}\text { Tanpa bordes, tanpa hand railling } \\
\text { dan tanpa pemisah antara jalur naik } \\
\text { dan jalur turun. Tidak terdapat } \\
\text { signage, tidak terdapat tanaman dan } \\
\text { tidak terdapat fasilitas untuk disable. } \\
\text { Terdapat tempat sampah dan lampu } \\
\text { penerangan }\end{array}$ & $\begin{array}{l}\text { terdapat signage, tanaman, } \\
\text { tempat duduk, lampu }\end{array}$ & $\begin{array}{l}\text { Terdapat tanamam pembatas, } \\
\text { sigange }\end{array}$ \\
\hline 8 & Visual & $\begin{array}{l}\text { Bersih, terdapat lebih dari satu } \\
\text { suara yang tertangkap, terdapat } \\
\text { bau-bau yang tertangkap dari area } \\
\text { resto, padat }\end{array}$ & $\begin{array}{l}\text { Bersih, terdapat lebih dari satu } \\
\text { suara yang tertangkap, terdapat } \\
\text { bau-bau yang tertangkap dari area } \\
\text { resto, padat }\end{array}$ & $\begin{array}{l}\text { Bersih, terdapat lebih dari satu } \\
\text { suara yang tertangkap, terdapat } \\
\text { bau-bau yang tertangkap dari } \\
\text { area resto, padat }\end{array}$ \\
\hline
\end{tabular}

Sumber: Analisa Pribadi, 2020 


\section{HASIL DAN PEMBAHASAN}

Dari hasil pengamatan penulis dan hasil sebaran kuesioner terhadap 40 responden, didapatkan hasil temuannya sebagai berikut :

\section{Pejalan kaki memilih melewati anak tangga}

Diagram dibawah menggambarkan jumlah tujuan/motiv pejalan kaki dalam 2 kategori yaitu memilih melewati anak tangga dan menghindari anak tangga ketika berjalan pada ruang transisi obyek studi.

Tujuan/Motiv memilih melewati anak tangga ketika berjalan pada ruang transisi obyek studi mendapat urutan yang pertama dengan jumlah mencapai $90 \%$ atau 36 responden $(N=40)$. Sedangkan tujuan/motiv menghindari anak tangga ketika berjalan pada ruang transisi obyek studi, mendapat urutan yang kedua dengan jumlah mencapai $10 \%$ atau 4 responden $(\mathrm{N}=40)$.

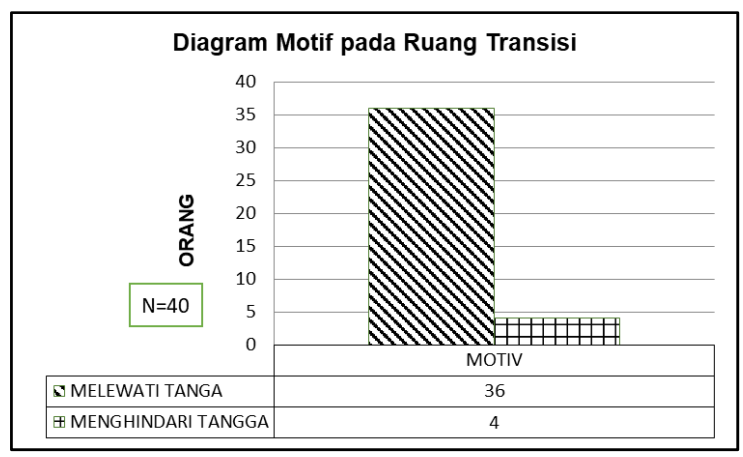

Gambar 2 Diagram Tujuan/motiv Ruang Transisi (Sumber: Data Penulis, 2020)

Dari hasil temuan diatas menunjukkan bahwa, melewati anak tangga lebih diminati pejalan kaki dibandingkan menghindarinya. Hal ini disebabkan oleh :

a. Pejalan kaki merasa kepanasan pada ruang transisi

Kecenderungan tertinggi hubungan tujuan/motiv melewati anak tangga dengan atribut kenyamanan fisik pejalan kaki pada ruang transisi dapat dilihat dari kuatnya nilai hubungan yang dirasakan dari 36 pejalan kaki yang merasa kepanasan dengan pernyataan setuju sebanyak $32(n=36)$ dengan nilai mean 26.7 (lihat diagram gambar 3). Nilai tersebut menunjukkan bahwa pejalan kaki merasa kepanasan ketika berjalan pada ruang transisi, dalam arti kulit terasa tersengat, berkeringat dan ingin segera mencari tempat yang teduh.

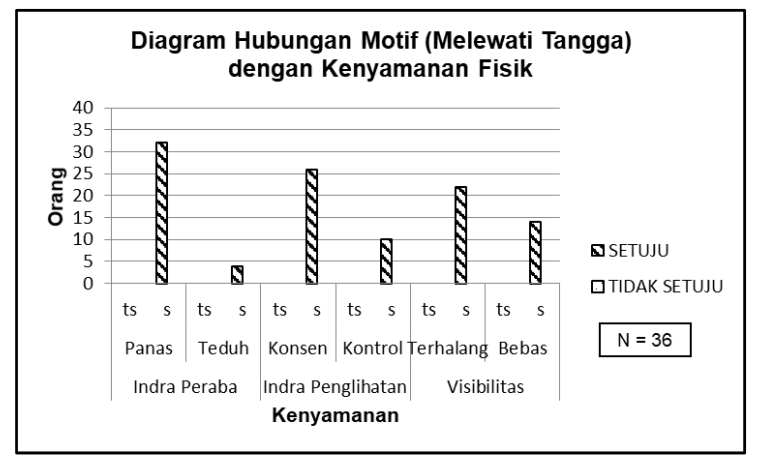

Gambar 3 Diagram Hubungan Tujuan/motiv (MelewatiTangga) dengan Kenyamanan Fisik (Sumber: Data Penulis, 2020)

Gambar 4, 5, 6, 7 menunjukkan bentuk ruang transisi obyek studi. Secara umum bentuk ruang transisi menunjukkan mayoritas ruang yang merupakan area terbuka tanpa penutup atap. Hanya pada bagian anak tangga, selasar dan pada area main entrance mall saja yang tertutup oleh kanopi.
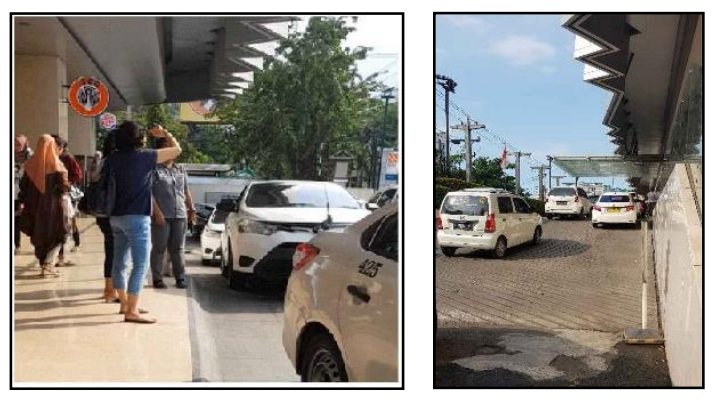

Gambar 4 Eksisting Ruang Transisi Area Terbuka (Sumber: Data Penulis, 2020)

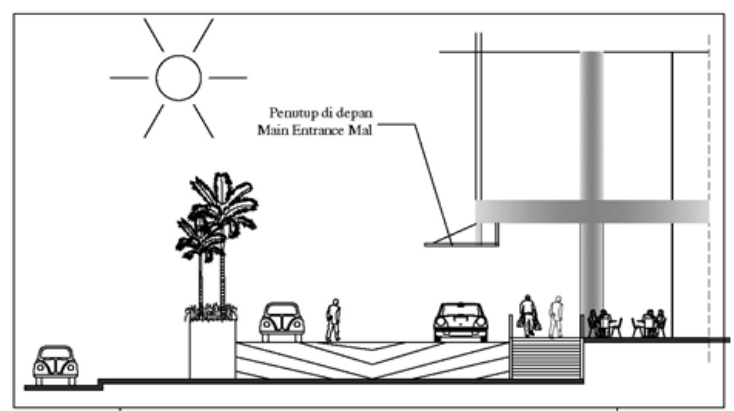

Gambar 5 Bentuk Ruang Transisi (Ruang Terbuka, Anak Tangga Dan Selasar) (Sumber: data Penulis, 2020) 


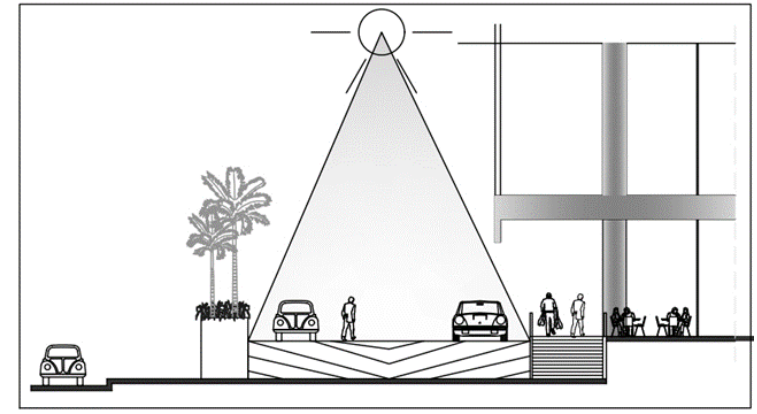

Gambar 6 Area Terbuka Terpapar Sinar Matahari Siang Hari

(Sumber: Data Penulis, 2020)

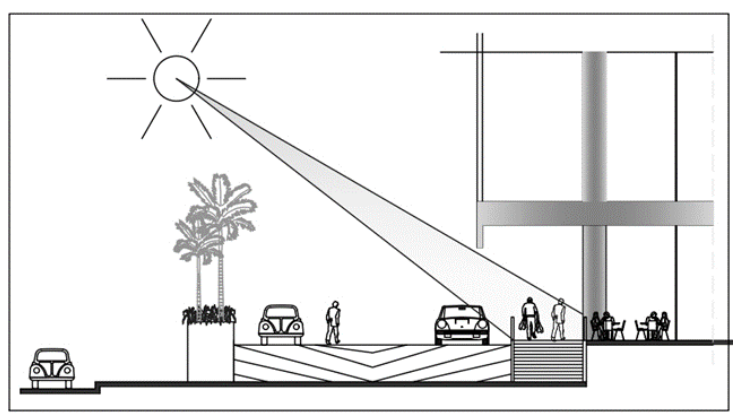

Gambar 7 Anak Tangga dan Selasar Terpapar Sinar Matahari Siang Hari

(Sumber: Data Penulis, 2020)

Dari gambar gambar 4, 5, 6, 7 diatas dapat dilihat bahwa, seting ruang transisi terutama pada area terbuka, menyebabkan pengguna pejalan kaki dapat terpapar matahari langsung. Sedangkan pada area selasar dan anak tangga hanya terpapar matahari langsung diatas pukul $14.00 \mathrm{WIB}$, karena pada bagian atasnya tertutup dengan kanopi.

Dengan ukuran ruang transisi seperti terlihat pada gambar 1 dan banyaknya pengguna baik pejalan kaki maupun asap kendaraan bermotor yang berada pada ruang ini, maka menyebabkan keadaan menjadi lebih panas. Pemilihan warna dinding dan lantai ruang transisi yaitu warna orange menambah suasana menjadi lebih panas, karena sifat warna orange yang termasuk dalam warna panas. Beberapa hal diatas menjadi alasan pengguna pejalan kaki merasa panas dan lebih memilih melewati anak tangga yang cenderung lebih tertutup terhadap matahari.

b. Pejalan kaki merasa tidak ada pembatas pada ruang transisi

Kecenderungan tertinggi hubungan tujuan/motiv melewati anak tangga dengan atribut kenyamanan sirkulasi dapat dilihat dari kuatnya nilai hubungan yang dirasakan dari 36 pejalan kaki yang merasa tidak ada batas yang jelas antara pejalan kaki dengan kendaraan bermotor, dengan pernyataan setuju sebanyak $26(n=36)$ dengan nilai mean 23.5 (lihat diagram gambar 8). Dari nilai tersebut menunjukkan bahwa pejalan kaki merasa tidak ada kejelasan batas ketika berjalan pada ruang transisi, baik kejelasan batas antar pejalan kaki yang masuk dan keluar mall, maupun kejelasan batas antara pejalan kaki dengan kendaraan bermotor.

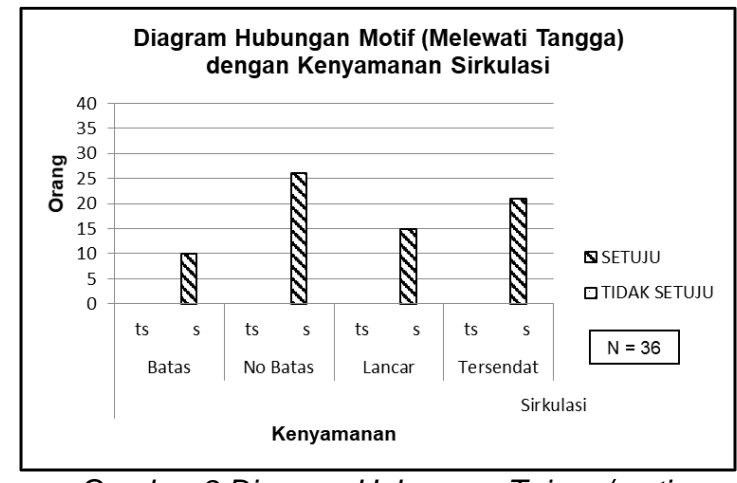

Gambar 8 Diagram Hubungan Tujuan/motiv (MelewatiTangga) dengan Kenyamanan Sirkulasi (Sumber: Data Penulis, 2020)

Gambar 10 menujukkan denah ruang transisi obyek studi, dimana pembatas yang tampak hanya pada area sebelah kanan anak tangga yang berbatasan dengan area terbuka hingga sampai pada sebagian sisi selasar. Dan gambar 9 dan 11 menunjukkan ilustrasi pada zona 1, 2 dan 3 terkait sikap pejalan kaki akibat tidak adanya pembatas yang jelas yang mengakibatkan terjadinya tabrakan antar pejalan kaki dan antara pejalan kaki dengan kendaraan bermotor.
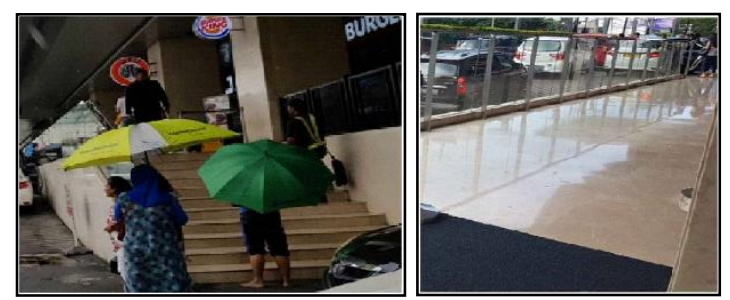

Gambar 9 Eksisting Ruang Transisi Tanpa Pembatas (Sumber: Data Penulis, 2020) 


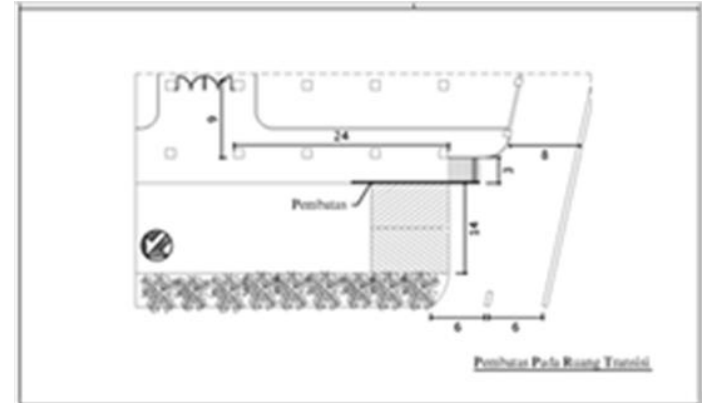

Gambar 10 Posisi Pembatas Pada Ruang Transisi (Sumber: Data Penulis, 2020)

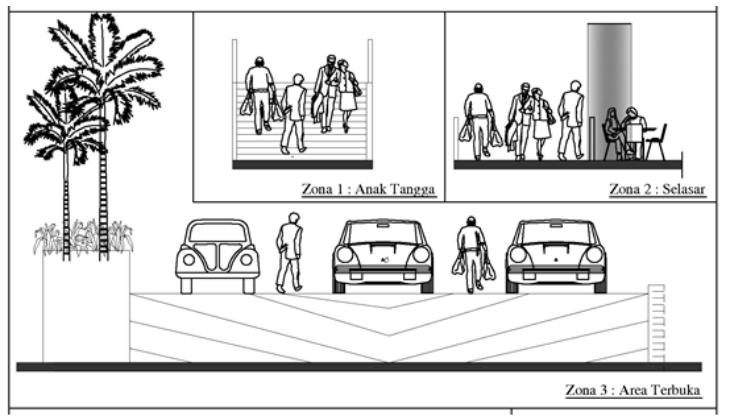

Gambar 11 Ketidakjelasan Batas pada Zona 1, 2, 3 (Sumber: data Penulis, 2020)

Pengguna pejalan kaki merasa bahwa pada ruang transisi obyek studi tidak terdapat batas yang jelas antara pengguna pejalan kaki dan kendaraan bermotor, sehingga pejalan kaki mencari jalan masing-masing untuk menghindari tertabrak. Satu-satunya area yang memisahkan jalur kendaraan dan pejalan kaki adalah melewati anak tangga.

Dari gambar 9 dan 11 diatas, dapat dilihat bahwa, bentuk ruang transisi pada area terbuka tidak ada pembatas yang jelas, baik pembatas antar pejalan kaki, maupun pembatas antara pejalan kaki dengan kendaraan. Sedangkan pada area anak tangga, juga tidak terdapat pembatas yang jelas antara pejalan kaki yang naik maupun pejalan kaki yang menuruni tangga. Begitu juga pada area selasar, tidak terdapat pembatas yang jelas antara pejalan kaki yang mau memasuki mall dan yang mau pulang dari mall. Hal ini tentu membuat pejalan kaki tidak nyaman, terutama pada area terbuka

yang tidak ada pembatas dengan kendaraan bermotor. Keadaan ini tentunya menyebabkan pengguna lebih memilih menggunakan anak tangga yang keberadaannya terpisah dengan kendaraan bermotor.

c. Pejalan kaki merasa kesulitan beraktifitas pada ruang transisi
Kecenderungan tertinggi hubungan tujuan/motiv melewati anak tangga dengan atribut kenyamanan aksesibilitas dapat dilihat dari kuatnya nilai hubungan yang dirasakan dari 36 pejalan kaki yang merasa kesulitan beraktifitas ketika berjalan di area ruang transisi, dengan pernyataan setuju sebanyak $29 \quad(n=36)$ dengan nilai mean 24.8 (lihat diagram gambar 12). Nilai tersebut menunjukkan bahwa pejalan kaki merasa kesulitan beraktifitas ketika sedang berjalan pada ruang transisi, seperti terputusnya pembicaraan pada saat berjalan karena berpapasan dengan kendaraan bermotor ataupun berpapasan dengan pejalan kaki lainnya.

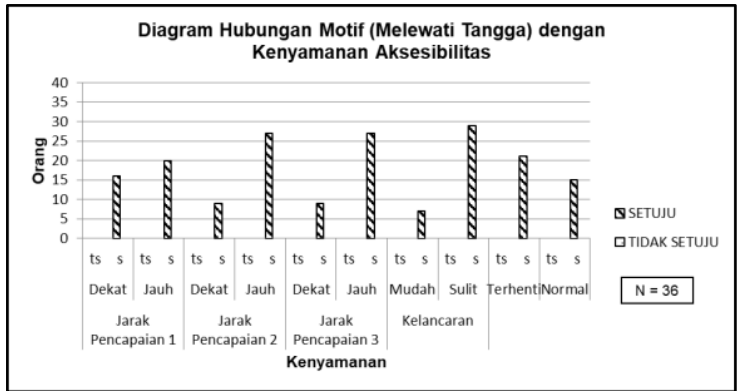

Gambar 12 Diagram Hubungan Tujuan/motiv (MelewatiTangga) dengan Kenyamanan Aksesibilitas (Sumber: Data Penulis, 2020)

Gambar 13 dan 14 menunjukkan kondisi pada seting ruang transisi obyek studi, dimana aktifitas pejalan kaki seperti percakapan terganggu ketika pejalan kaki berpapasan dengan pejalan kaki lainnya atau berpapasan dengan kendaraan bermotor, baik pada area anak tangga, selasar maupun area terbuka.

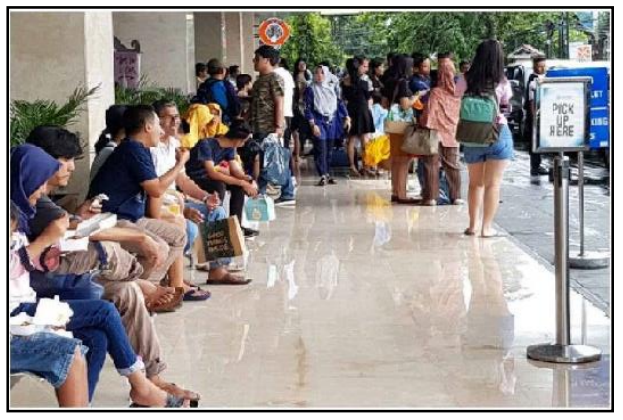

Gambar 13 Eksisting Ruang Transisi Yang Menyulitkan Aktivitas Pengguna (Sumber: Data Penulis, 2020) 


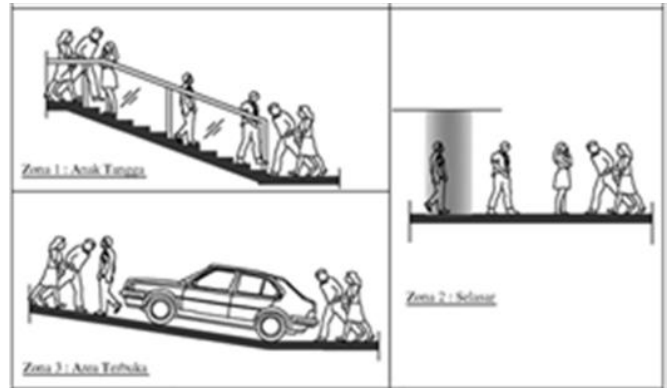

Gambar 14 Ilustrasi aktivitas percakapan pada ruang transisi

(Sumber: data Penulis, 2020)

Dari gambar 13 dan 14 diatas, dapat dilihat bahwa ketika pejalan kaki berpapasan dengan pejalan kaki lainnya atau berpapasan dengan kendaraan pada ruang trasisi, baik pada area terbuka, anak tangga maupun pada selasar, aksesibilitasnya sulit, karena aktivitas lain pejalan kaki, seperti percakapannya harus terhenti akibat bertabrakan dengan pejalan kaki yang lain. Apalagi ketika percakapan harus terputus karena bertabrakan dengan kendaraan bermotor, tentunya sangat berbahaya, sehingga pejalan kaki cenderung lebih memilih menggunakan anak tangga ketika berjalan kaki sambil bercakap-cakap dengan pejalan kaki lainnya.

d. Pejalan kaki merasa jarak pencapaian di ruang transisi tidak efektif

Kecenderungan tertinggi hubungan tujuan/motiv melewati anak tangga dengan atribut kenyamanan aksesibilitas lainnya dapat dilihat dari kuatnya nilai hubungan yang dirasakan dari 36 pejalan kaki yang merasa jauh ketika berjalan di zona 2 dan 3 , dengan pernyataan setuju sebanyak $27(n=36)$ dengan nilai mean 24.8 (lihat diagram gambar 12). Zona 2 yang dimaksudkan adalah area selasar setelah anak tangga sampai dengan pintu masuk utama mall, sedangkan zona 3 yang dimaksud adalah area terbuka setelah pagar pintu masuk kawasan sampai dengan anak tangga. Nilai tersebut menunjukkan bahwa pejalan kaki merasa jauh ketika berjalan pada zona tersebut, karena harus menghindari kerumunan orang dan kendaraan bermotor.

Dari gambar 15 dan 16 tampak adanya beberapa titik tunggu pengguna ruang yang menyebabkan pejalan kaki merasa terganggu perjalanannya menuju pintu masuk utama mall, harus menghindari beberapa kerumunan orang dan menghindari kendaraan.

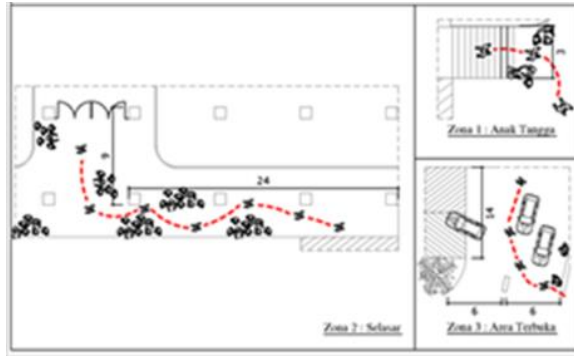

Gambar 15 Eksisting Ruang Transisi Terkait Jarak Pencapaian Yang Tidak Efektif (Sumber: data Penulis, 2020)
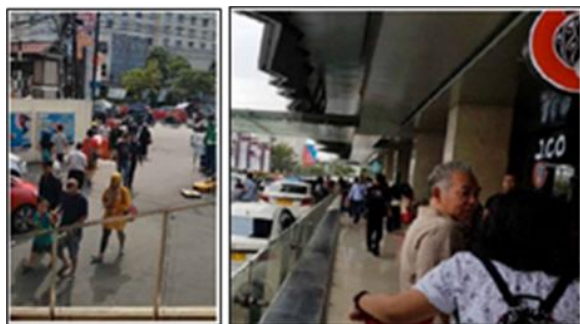

Gambar 16 Beberapa titik tunggu yang harus dihindari pejalan kaki

(Sumber: data Penulis, 2020)

Pengguna pejalan kaki merasa bahwa jarak pencapaian pada ruang transisi cukup jauh, terutama pada zona $2(31 \mathrm{~m})$ dan zona $3(14$ $\mathrm{m})$, dalam arti pengguna pejalan kaki harus menunggu kendaraan lewat dulu, atau pengguna pejalan kaki harus menghindari kerumunan orang jika berjalan pada ruang transisi ini. Untuk alasan itulah maka pengguna pejalan kaki lebih memilih melewati tangga supaya terpisah dari kendaraan bermotor.

\section{Pejalan kaki ingin segera sampai pada pintu masuk utama mall}

Diagram dibawah menggambarkan jumlah tujuan minat pejalan kaki dalam 2 kategori yaitu tujuan minat untuk dapat segera menuju ke tempat pintu masuk utama mall dan tujuan minat untuk dapat berjalan dengan santai (dalam arti tidak tergesa-gesa) pada ruang transisi obyek studi.



Gambar 17 Diagram Tujuan Minat Pada Ruang Transisi Sumber: Data Penulis, 2020 
Tujuan minat dapat segera menuju ke tempat yang diinginkan (dalam hal ini adalah ingin segera sampai pintu masuk utama mall obyek studi) mendapat urutan yang pertama dengan jumlah mencapai $65 \%$ atau 26 responden $(\mathrm{N}=$ 40) dari 40 responden.

Dari hasil temuan diatas menunjukkan bahwa, pejalan kaki merasa ingin segera sampai pada tujuan yaitu pintu utama obyek studi, dari pada berjalan santai atau berlama-lama di area ruang transisi. Hal ini disebabkan oleh :

a. Pejalan kaki merasa kepanasan berada di ruang transisi

Kecenderungan tertinggi hubungan tujuan minat ingin segera sampai pada pintu utama mall, dengan kenyamanan fisik dapat dilihat dari kuatnya nilai hubungan yang dirasakan dari 26 pejalan kaki yang merasa kepanasan dengan pernyataan setuju sebanyak $22(n=26)$ dengan nilai mean 19 (lihat diagram gambar 18). Nilai tersebut menunjukkan bahwa pejalan kaki merasa kepanasan ketika berjalan pada ruang transisi, dalam arti kulit terasa tersengat, berkeringat dan ingin segera mencari tempat yang teduh.

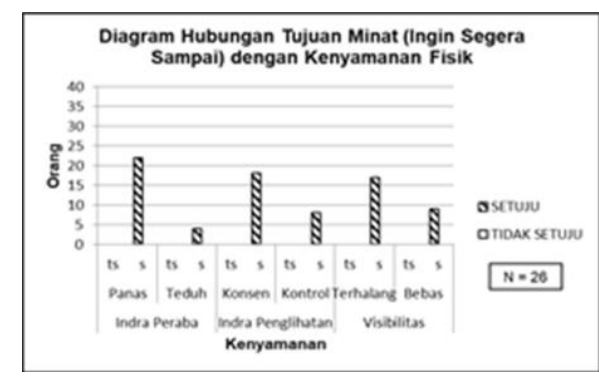

Gambar 18 Diagram Hubungan Tujuan Minat (Ingin Segera Sampai) dengan Kenyamanan Fisik

(Sumber: Data Penulis, 2020)

Realitasnya, mengacu pada gambar 4, 5, 6, 7 pejalan kaki merasa bahwa ruang transisi obyek studi adalah panas, sehingga pengguna pejalan kaki harus berjalan lebih cepat agar segera sampai ke tempat teduh dan sinar matahari dirasa menyengat kulit, sampai berkeringat. Hal ini menyebabkan pejalan kaki merasa ingin segera mencapai tujuannya, yaitu pintu masuk utama obyek studi.

b. Pejalan kaki merasa tidak ada pembatas pada ruang transisi

Kecenderungan tertinggi hubungan tujuan minat ingin segera sampai pada pintu utama mall, dengan kenyamanan sirkulasi dapat dilihat dari kuatnya nilai hubungan yang dirasakan dari 26 pejalan kaki yang merasa tidak ada batas yang jelas antara pejalan kaki dengan kendaraan bermotor, dengan pernyataan setuju sebanyak $17(n=26)$ dengan nilai mean 16 (lihat diagram gambar 19). Nilai tersebut menunjukkan bahwa pejalan kaki merasa tidak ada kejelasan batas ketika berjalan pada ruang transisi, sehingga memilih untuk sesegera mungkin meninggalkan ruang transisi menuju pintu utama obyek studi.



Gambar 19 Diagram Hubungan Tujuan Minat (Ingin Segera Sampai) dengan Kenyamanan Sirkulasi (Sumber: Data Penulis, 2020)

Realitasnya mengacu pada gambar 9 dan 11, pejalan kaki merasa bahwa pada ruang transisi obyek studi tidak terdapat batas yang jelas antara pengguna pejalan kaki dan kendaraan bermotor, sehingga pejalan kaki mencari jalan masing-masing untuk menghindari tertabrak, baik tertabrak kendaraan maupun tertabrak pejalan kaki lainnya. Hal ini tentu membuat pejalan kaki tidak nyaman, sehingga pejalan kaki merasa ingin segera meninggalkan ruang transisi untuk segera mencapai tujuannya yaitu pintu masuk obyek studi.

c. Pejalan kaki merasa kesulitan beraktifitas pada ruang transisi

Kecenderungan tertinggi hubungan tujuan minat ingin segera sampai pada pintu utama mall, dengan kenyamanan aksesibilitas dapat dilihat dari kuatnya nilai hubungan yang dirasakan dari 26 pejalan kaki yang merasa kesulitan beraktifitas ketika berjalan di area ruang transisi, dengan pernyataan setuju sebanyak $19(n=26)$ dengan nilain mean 16,2 (lihat diagram gambar 20). Nilai tersebut menunjukkan bahwa pejalan kaki merasa kesulitan beraktifitas ketika sedang berjalan, seperti terputusnya pembicaraan pada saat berjalan karena berpapasan dengan kendaraan. 


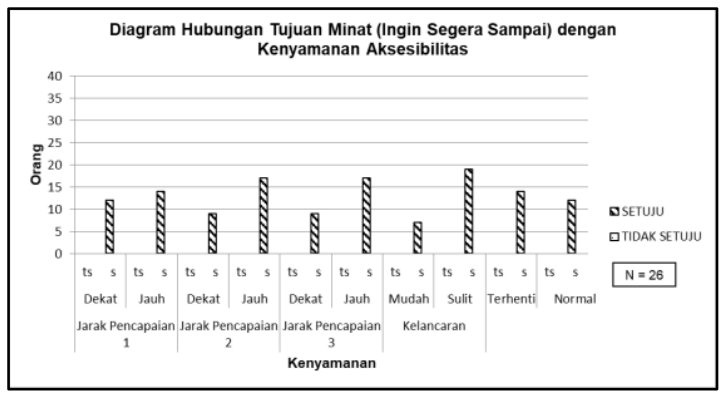

Gambar 20 Diagram Hubungan Tujuan Minat (Ingin Segera Sampai) dengan Kenyamanan Aksesibilitas (Sumber: Data Penulis, 2020)

Realitasnya mengacu pada gambar 13 dan 14, pejalan kaki merasa bahwa aksesibilitas pengguna ketika berjalan pada ruang transisi Obyek studi adalah sulit, dalam arti bahwa setiap bertemu / berpapasan dengan pejalan kaki lainnya atau kendaraan harus berhenti dan aktivitas lain seperti pembicaraan terputus. Hal ini tentu membuat pejalan kaki tidak nyaman, sehingga pejalan kaki merasa ingin segera meninggalkan ruang transisi untuk segera mencapai tujuannya yaitu pintu masuk obyek studi.

\section{d. Pejalan kaki merasa jarak pencapaian ruang} transisi tidak efektif

Kecenderungan tertinggi hubungan tujuan minat ingin segera sampai pintu utama mall dengan atribut kenyamanan aksesibilitas lainnya dapat dilihat dari kuatnya nilai hubungan yang dirasakan dari 26 pejalan kaki yang merasa jauh ketika berjalan di zona 2 dan 3, dengan pernyataan setuju sebanyak 17 $(n=26)$ dengan nilai mean 16.2 (lihat diagram gambar 20). Zona 2 yang dimaksudkan adalah area selasar setelah anak tangga sampai dengan pintu masuk utama mall, sedangkan zona 3 yang dimaksud adalah area terbuka setelah pagar pintu masuk kawasan sampai dengan anak tangga. Nilai tersebut menunjukkan bahwa pejalan kaki merasa jauh ketika berjalan pada zona tersebut, karena harus menghindari kerumunan orang dan kendaraan bermotor.

Realitasnya mengacu pada gambar 15 dan 16 , pejalan kaki merasa bahwa jarak pencapaian pada ruang transisi cukup jauh terutama pada zona 2 (31 m) dan zona 3 (14 m), dalam arti pengguna pejalan kaki harus menunggu kendaraan lewat dulu, atau pengguna pejalan kaki harus menghindari kerumunan orang jika berjalan pada ruang transisi ini. Untuk alasan itulah maka pengguna pejalan kaki ingin sesegera mungkin meninggalkan ruang transisi menuju pintu utama mall.

\section{Pejalan kaki ingin keadaan aman pada ruang transisi}

Diagram dibawah menggambarkan jumlah rasa minat pejalan kaki dalam 2 kategori yaitu rasa minat untuk aman terhadap kendaraan bermotor ketika berjalan pada ruang transisi obyek studi dan rasa minat untuk lancar berpapasan dengan pejalan kaki lainnya, dalam arti tidak bersinggungan ketika berjalan pada ruang transisi obyek studi.

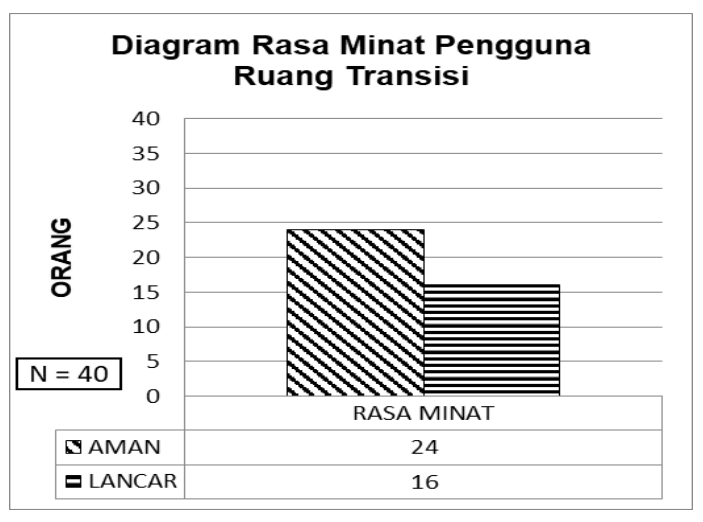

Gambar 21 Diagram Rasa Minat pada Ruang Transisi (Sumber: Data Penulis, 2020)

Rasa minat untuk aman terhadap kendaraan bermotor ketika berjalan pada ruang transisi obyek studi mendapat urutan yang pertama dengan jumlah mencapai $60 \%$ atau 24 responden $(N=40)$ dari 40 responden.

Dari hasil temuan diatas menunjukkan bahwa, pejalan kaki ingin merasa lebih aman ketika berjalan pada ruang transisi obyek studi daripada keinginan terhadap lancarnya kegiatan berjalan kaki. Hal ini disebabkan:

a. Pada ruang transisi terasa panas Kecenderungan tertinggi hubungan rasa minat (aman) dengan kenyamanan fisik dapat dilihat dari kuatnya nilai hubungan yang dirasakan dari 24 pejalan kaki yang merasa kepanasan dengan pernyataan setuju sebanyak $23(n=24)$ dengan nilai mean 18.3 (lihat diagram gambar 22). Nilai tersebut menunjukkan bahwa pejalan kaki merasa kepanasan ketika berjalan pada ruang transisi, dalam arti kulit terasa tersengat, berkeringat, banyak asap kendaraan, yang menyebabkan pejalan kaki merasa perlunya keamanan pada ruang transisi ini. 


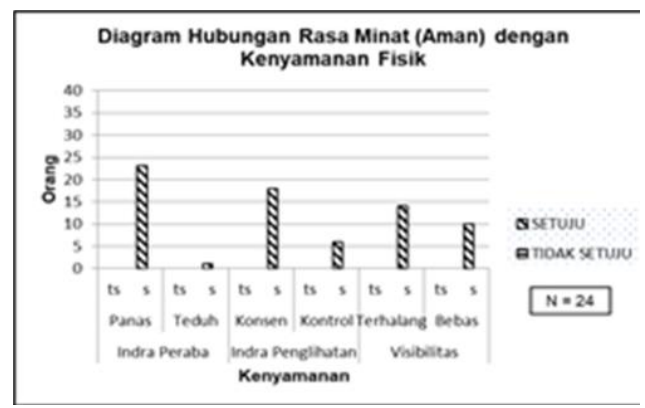

Gambar 22 Diagram Hubungan Rasa Minat (Aman) dengan Kenyamanan Fisik

(Sumber: Data Penulis, 2020)

Realitasnya mengacu pada gambar 4, 5, 6, 7 pengguna pejalan kaki merasa bahwa ruang transisi obyek studi adalah panas, sinar matahari dirasa menyengat kulit, sampai berkeringat dan banyaknya asap kendaraan juga menjadi penyebab ruang transisi menjadi panas dan tidak aman bagi kesehatan pejalan kaki. Kondisi ini tentu saja tidak bagus bagi tubuh manusia, jika berlama-lama berada di ruang transisi ini, oleh karena itulah pejalan kaki merasakan keinginan akan keadaan yang aman pada ruang transisi.

b. Pada ruang transisi tidak ada pembatas Kecenderungan tertinggi hubungan rasa minat (aman) dengan kenyamanan sirkulasi dapat dilihat dari kuatnya nilai hubungan yang dirasakan dari 24 pejalan kaki yang merasa tidak ada batas yang jelas antara pejalan kaki dengan kendaraan bermotor, dengan pernyataan setuju sebanyak $18(n=24)$ dengan nilai mean 16.5 (lihat diagram gambar 23). Nilai tersebut menunjukkan bahwa pejalan kaki merasa tidak ada kejelasan batas ketika berjalan pada ruang transisi, terutama batas antara pejalan kaki dengan kendaraan bermotor, sehingga pejalan merasa tidak aman berada pada ruang transisi.

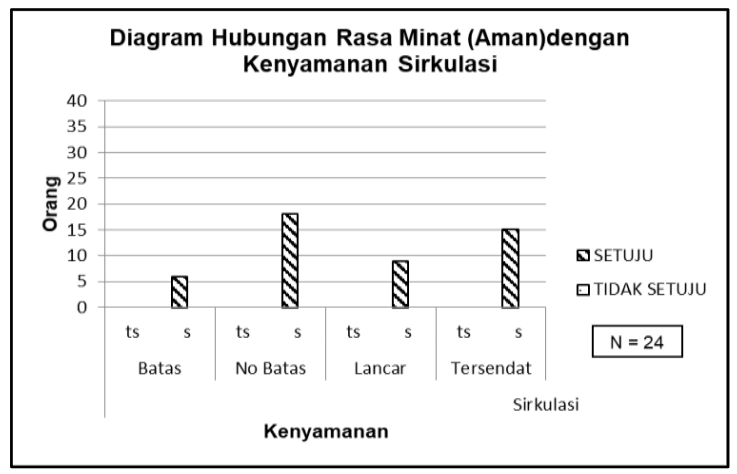

Gambar 23 Diagram Hubungan Rasa Minat (Aman) dengan Kenyamanan Sirkulasi (Sumber: Data Penulis, 2020)
Realitasnya mengacu pada gambar 9, 11, pejalan kaki merasa bahwa pada ruang transisi obyek studi tidak terdapat batas yang jelas antar pejalan kaki dan antara pengguna pejalan kaki dengan kendaraan bermotor, sehingga pejalan kaki mencari jalan masingmasing untuk menghindari tertabrak, baik tertabrak kendaraan maupun tertabrak pejalan kaki lainnya. Hal ini tentu membuat pejalan kaki tidak aman, karena resiko tertabrak kendaraan bermotor pada area terbuka, atau anak kecil yang tertabrak sesama pejalan kaki yang berpapasan di area tangga dan selasar. Sehingga pejalan kaki lebih merasa membutuhkan keamanan pada area ini dibandingkan kelancaran pejalan kaki.

c. Pada ruang transisi pejalan kaki kesulitan beraktifitas

Kecenderungan tertinggi hubungan rasa minat (aman) dengan kenyamanan aksesibilitas dapat dilihat dari kuatnya nilai hubungan yang dirasakan dari 24 pejalan kaki, yang merasa kesulitan beraktifitas ketika berjalan di area ruang transisi, dengan pernyataan setuju sebanyak $22(n=24)$ dengan nilain mean 17.6 (lihat diagram gambar 24). Nilai tersebut menunjukkan bahwa pejalan kaki merasa kesulitan beraktifitas ketika sedang berjalan, seperti terputusnya pembicaraan pada saat berjalan karena berpapasan dengan kendaraan. Hal ini dinilai pejalan kaki sebagai keadaan yang membahayakan diri, sehingga pejalan kaki lebih menginginkan rasa aman ketika berada pada ruang transisi daripada rasa lancar.

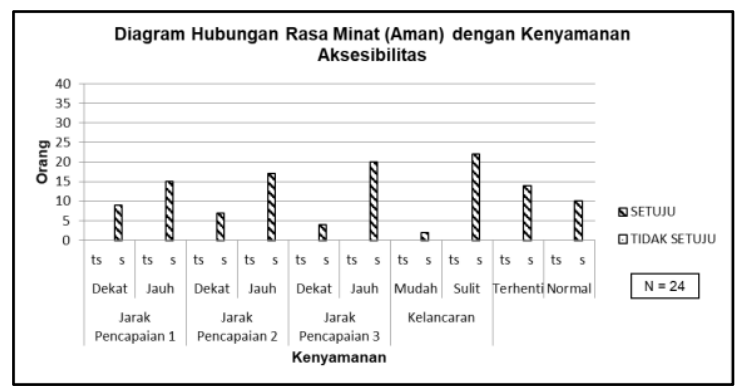

Gambar 24 Diagram Hubungan Rasa Minat (Aman) dengan Kenyamanan Aksesibilitas

(Sumber: Data Penulis, 2020)

Realitasnya mengacu pada gambar 13 dan 14 , pejalan kaki merasa bahwa aksesibilitas pengguna ketika berjalan pada ruang transisi obyek studi adalah sulit, dalam arti bahwa setiap bertemu / berpapasan dengan pengguna lainnya terutama dengan kendaraan bermotor, pejalan kaki harus berhenti dan aktivitas lain seperti pembicaraan terputus, karena jika dilanjutkan akan membahayakan 
diri sendiri. Hal ini tentu membuat pejalan kaki tidak nyaman, sehingga pejalan kaki lebih menginginkan keadaan aman pada ruang transisi dibandingkan kelancaran dalam berjalan kaki.

d. Pada ruang transisi jarak pencapaian tidak efektif

Kecenderungan tertinggi hubungan rasa minat ingin aman dengan atribut kenyamanan aksesibilitas lainnya dapat dilihat dari kuatnya nilai hubungan yang dirasakan dari 24 pejalan kaki yang merasa jauh ketika berjalan di zona 3 , dengan pernyataan setuju sebanyak 20 $(n=24)$ dengan nilai mean 17.6 (lihat diagram gambar 24). Zona 3 yang dimaksud adalah area terbuka setelah pagar pintu masuk kawasan sampai dengan anak tangga. Nilai tersebut menunjukkan bahwa pejalan kaki merasa jauh ketika berjalan pada zona tersebut, karena harus menghindari kerumunan orang dan kendaraan bermotor.

Realitasnya mengacu pada gambar 15 dan 16 , pengguna pejalan kaki merasa bahwa jarak pencapaian pada ruang transisi cukup jauh terutama pada zona $3(14 \mathrm{~m})$, dalam arti pengguna pejalan kaki harus menunggu kendaraan lewat dulu dan harus menghindari beberapa kerumunan orang dan menghindari kendaraan. Keadaan ini dinilai tidak aman bagi pengguna, sehingga pengguna lebih menginginkan rasa aman ketika berada diruang transisi daripada kelancaran.

\section{Pejalan kaki berharap adanya modifikasi pada seting ruang transisi}

Diagram dibawah menggambarkan jumlah harapan pejalan kaki dalam 2 kategori yaitu kategori yang menganggap kondisi sudah baik dan tidak perlu modifikasi dan kategori perlunya modifikasi pada ruang transisi obyek studi.

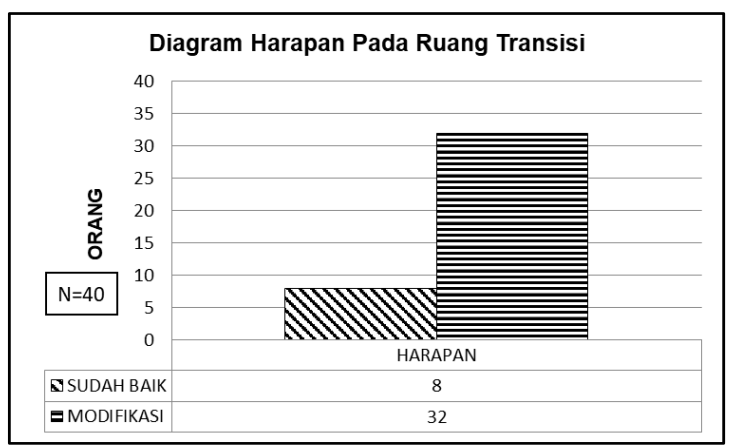

Gambar 25 Diagram Harapan Pejalan Kaki Terhadap Ruang Transisi

Sumber: Data Penulis, 2020
Harapan perlunya modifikasi pada ruang transisi obyek studi, mendapat urutan yang pertama dengan jumlah mencapai $80 \%$ atau 32 responden $(\mathrm{N}=40)$ dari 40 responden.

Dari hasil temuan diatas menunjukkan bahwa, pejalan kaki merasa perlu adanya modifikasi atau perbaikan desain pada ruang transisi obyek studi. Hal ini mempunyai tujuan :

a. Ruang transisi tidak panas bagi pejalan kaki Kecenderungan tertinggi hubungan harapan perlunya modifikasi dengan kenyamanan fisik dapat dilihat dari kuatnya nilai hubungan yang dirasakan dari 32 pejalan kaki yang merasa kepanasan dengan pernyataan setuju sebanyak $29(n=32)$ dengan nilai mean 24.3 (lihat diagram gambar 26). Nilai tersebut menunjukkan bahwa pejalan kaki merasa kepanasan ketika berjalan pada ruang transisi, dalam arti kulit terasa tersengat, berkeringat, terutama pada area terbuka yang terdapat kendaraan bermotor dan ingin segera mencari tempat yang teduh. Keadaan ini membuat pejalan kaki menganggap perlunya modifikasi atau perbaikan desain pada ruang transisi.

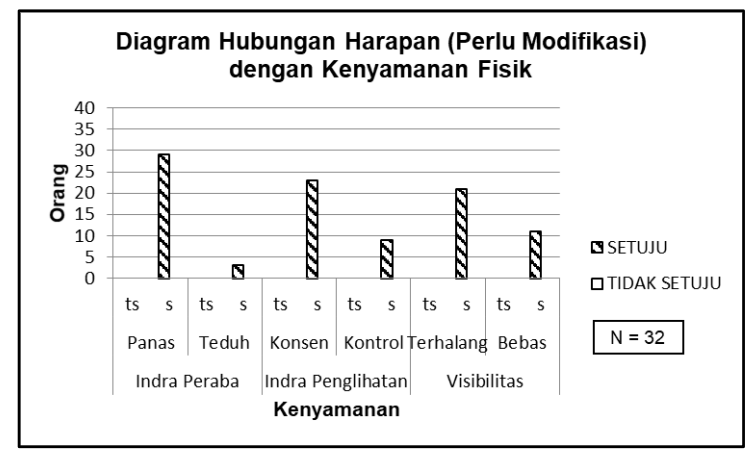

Gambar 26 Diagram Hubungan Harapan (Perlu Modifikasi) dengan Kenyamanan Fisik Sumber: Data Penulis, 2020

Realitasnya mengacu pada gambar 4, 5, 6, 7 pejalan kaki merasa bahwa ruang transisi obyek studi adalah panas, sehingga pengguna pejalan kaki harus berjalan lebih cepat agar segera sampai ke tempat teduh, sinar matahari dirasa menyengat kulit, sampai berkeringat. Kondisi tentu saja tidak nyaman bagi pejalan kaki. Hal ini menyebabkan pengguna pejalan kaki merasa panas dan merasa tidak nyaman. Sehingga pejalan kaki menginginkan adanya modifikasi atau perbaikan desain pada ruang transisi agar suasana ruang transisi menjadi lebih teduh.

b. Perlunya pembatas pada ruang transisi Kecenderungan tertinggi hubungan harapan perlunya modifikasi dengan kenyamanan sirkulasi dapat dilihat dari kuatnya nilai 
hubungan yang dirasakan dari 32 pejalan kaki, yang merasa tidak ada batas yang jelas antara pejalan kaki dengan kendaraan bermotor, dengan pernyataan setuju sebanyak $23(n=32)$ dengan nilain mean 21 (lihat diagram gambar 27). Nilai tersebut menunjukkan bahwa pejalan kaki merasa tidak ada kejelasan batas antara pejalan kaki dengan kendaraan bermotor ketika berjalan pada ruang transisi, sehingga pejalan kaki merasa perlunya modifikasi atau perbaikan desain pada ruang transisi.

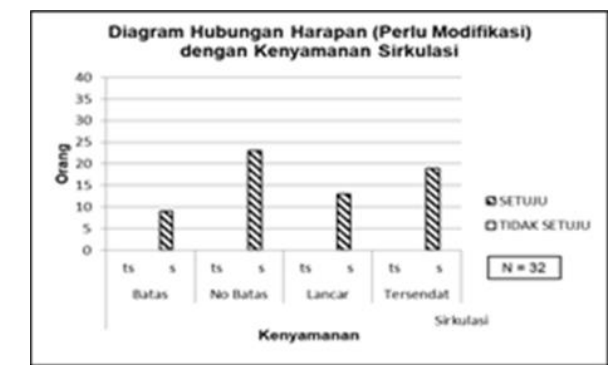

Gambar 27 Diagram Hubungan Harapan (Perlu Modifikasi) dengan Kenyamanan Sirkulasi

(Sumber: Data Penulis, 2020)

Realitasnya mengacu pada gambar 9, 11, pejalan kaki merasa bahwa pada ruang transisi obyek studi tidak terdapat batas yang jelas antar pejalan kaki dan antara pengguna pejalan kaki dengan kendaraan bermotor, sehingga pejalan kaki mencari jalan masingmasing untuk menghindari tertabrak, baik tertabrak kendaraan maupun tertabrak pejalan kaki lainnya. Hal ini tentu membuat pejalan kaki tidak nyaman, karena resiko tertabrak kendaraan bermotor pada area terbuka, atau anak kecil yang tertabrak sesama pejalan kaki yang berpapasan di area anak tangga dan selasar. Sehingga pejalan kaki merasa perlunya modifikasi atau perbaikan desain pada ruang transisi.

c. Perlunya jarak pencapaian yang efektif pada ruang transisi

Kecenderungn tertinggi hubungan harapan perlunya modifikasi dengan kenyamanan aksesibilitas dapat dilihat dari kuatnya nilai hubungan yang dirasakan dari 32 pejalan kaki, yang merasa jauh, karena pejalan kaki harus menunggu kendaraan lewat terlebih dahulu, dengan pernyataan setuju sebanyak $26(n=32)$ dengan nilai mean 22,4 (lihat diagram gambar 28). Nilai tersebut menunjukkan bahwa pejalan kaki merasa jarak pencapaian pada ruang transisi terutama pada zona 3 (area terbuka) tidak efektif, sehingga pejalan kaki merasa perlu adanya modifikasi atau perbaikan desain pada ruang transisi.

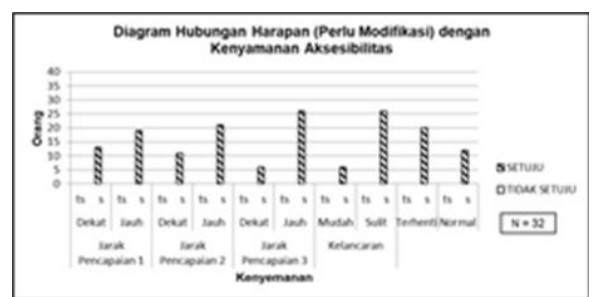

Gambar 28 Diagram Hubungan Harapan (Perlu Modifikasi) dengan Kenyamanan Aksesibilitas (Sumber: Data Penulis, 2020)

Realitasnya mengacu pada gambar 13 dan 14 , pejalan kaki merasa bahwa jarak pencapaian pada ruang transisi obyek studi, baik pada zona 1, 2 maupun pada zona 3, cukup jauh. Terutama pada zona $3(14 \mathrm{~m})$, dimana pengguna pejalan kaki harus menunggu kendaraan lewat dulu, atau pengguna pejalan kaki harus menghindari kerumunan orang jika berjalan pada ruang transisi ini. Untuk alasan itulah maka pengguna pejalan kaki merasa perlunya perbaikan atau modifikasi desain pada ruang transisi ini.

d. Ruang transisi tidak mendukung aktivitas pejalan kaki

Kecenderungan tertinggi hubungan harapan pejalan kaki dengan kenyamanan aksesibilitas lainnya, dapat dilihat dari kuatnya nilai hubungan yang dirasakan dari 32 pejalan kaki, yang merasa yang merasa kesulitan beraktifitas ketika berjalan di area ruang transisi, dengan pernyataan setuju sebanyak $26 \quad(n=32)$ dengan nilai mean 22.4. Nilai tersebut menunjukkan bahwa pejalan kaki merasa kesulitan beraktifitas ketika sedang berjalan, seperti terputusnya pembicaraan pada saat berjalan karena berpapasan dengan kendaraan, sehingga pejalan kaki merasa perlu adanya modifikasi atau perbaikan desain pada ruang transisi.

Realitasnya mengacu pada gambar 15 dan 16 , pejalan kaki merasa bahwa aksesibilitas pengguna ketika berjalan pada ruang transisi obyek studi adalah sulit, dalam arti bahwa setiap bertemu / berpapasan dengan pejalan kaki lainnya harus berhenti dan aktivitas lain seperti pembicaraan terputus. Hal ini tentu membuat pejalan kaki tidak nyaman, sehingga pejalan kaki merasa perlu adanya modifikasi atau perbaikan desain pada ruang transisi ini.

\section{KESIMPULAN}

Berdasarkan hasil kajian dan temuan diatas, maka dapat diambil kesimpulan bahwa secara jelas ada kaitan antara sikap pejalan kaki 
terhadap seting ruang transisi, terkait dengan atribut kenyamanan pejalan kaki.

Secara garis besar tuntutan atribut kenyamanan pada ruang transisi kurang terpenuhi sehingga menyebabkan ruang transisi tidak dapat berfungsi secara optimal. Adapun indikator atribut kenyamanan yang tidak terpenuhi adalah :

\section{Kenyamanan Fisik}

Pejalan kaki merasa tuntutan atribut kenyamanan terhadap indra peraba tidak terpenuhi. Ini disebabkan karena ketika pengguna pejalan kaki melewati ruang transisi merasa panas, sehingga pengguna pejalan kaki harus berjalan lebih cepat agar segera sampai ke tempat teduh, sinar matahari dirasa menyengat kulit, sampai berkeringat.

\section{Kenyamanan Sirkulasi}

Pejalan kaki merasa tuntutan atribut kenyamanan pada aspek sirkulasi tidak terpenuhi. Ini disebabkan karena ketika pengguna pejalan kaki melewati ruang transisi, merasa bahwa tidak ada batas yang jelas antar pengguna pejalan kaki dan antara pejalan kaki dengan kendaraan bermotor.

\section{Kenyamanan Aksesibilitas}

- Pejalan kaki merasa tuntutan atribut kenyamanan pada aspek aksesibilitas tidak terpenuhi. Ini disebabkan karena ketika pengguna pejalan kaki melewati ruang transisi merasa kesulitan dalam arti bahwa setiap bertemu / berpapasan dengan pejalan kaki lainnya harus berhenti dan aktivitas lain seperti pembicaraan terputus.

- Pejalan kaki merasa tuntutan atribut kenyamanan pada aspek jarak pencapaian tidak terpenuhi. Ini disebabkan karena ketika pejalan kaki melewati ruang transisi merasa jauh, karena pejalan kaki harus menghindari kerumuan orang dan harus menghindari kendaraan bermotor.

Tidak terpenuhinya tuntutan atribut pejalan kaki diatas disebabkan karena banyaknya jumlah pejalan kaki pada ruang transisi ini. Kondisi ini tidak sesuai dengan desain awal ruang transisi, dimana sebagian besar pengunjung direncanakan masuk ke dalam ruang parkir didalam gedung. Banyaknya jumlah pejalan kaki pada ruang transisi ini dipicu karena tidak optimalnya tata kelola parkir kendaraan pada gedung utama, dan tumbuhnya kantung-kantung parkir baru disekitar luar kawasan. Banyaknya pejalan kaki dan bercampurnya pejalan kaki dengan kendaraan bermotor, mendorong terjadinya kemacetan pada ruang transisi, yang mempengaruhi kenyamanan fisik, kenyamanan sirkulasi dan kenyamanan aksesibilitas pejalan kaki.

Berdasarkan hasil dari temuan dan pembahasan, agar fungsi ruang transisi dapat maksimal dan memenuhi atribut kenyamanan dari penggunanya, direkomendasikan sebagai berikut:

\section{Kepada Arsitek / Perancang Kota :}

Bahwa seorang arsitek dalam merancang ruang transisi harus memperhatikan hal-hal sebagai berikut :

a. Desain ruang transisi harus memenuhi atribut kenyamanan fisik pengguna terutama berhubungan dengan indra peraba, supaya tidak panas.

b. Desain ruang transisi harus memberikan kejelasan pembatas pengguna, baik kejelasan pembatas antar pejalan kaki yang keluar dan masuk ataupun kejelasan pembatas antara pejalan kaki dengan kendaraan bermotor.

c. Desain ruang transisi harus mampu mengakomodir kemudahan aktifitas pengguna pejalan kaki

d. Desain ruang transisi harus memperhatikan aspek sirkulasi pengguna dan dirancang supaya tidak menyebabkan timbulnya aktivitas baru seperti menunggu dan bergerombol sehingga menyebabkan pengguna merasa terganggu.

Terkait Alternatif Desain :

a. Pemisahan Jalur masuk dan jalur keluar ;

Rekomendasi pertama yang dapat digunakan, yaitu dengan mengatur sirkulasi pengguna pada ruang transisi dengan adanya pemisahan jalur. Pemisahan jalur yang direkomendasikan adalah pemisahan jalur antara pengguna pejalan kaki dengan pengguna kendaraan bermotor, serta pemisahan jalur antara arus masuk dengan arus keluar, baik arus keluar masuk pejalan kaki maupun arus keluar masuk kendaraan bermotor.

b. Pengaturan area service :

Aktifitas-aktifitas layanan seperti valet service, drop off, pick up dan VIP Park, sebaiknya diposisikan pada area yang terpisah dari jalur pengguna ruang transisi, sehingga tidak mengganggu aktifitas utama pengguna.

c. Pemenuhan atribut kenyamanan pada desain ruang transisi :

- Terkait dengan kenyamanan fisik, perlu dipertimbangkan agar suasana panas pada area publik bisa diminimalisir, apalagi untuk 
ruang transisi yang digunakan pada siang hari. Alternatifnya adalah penggunaan tanaman sebagai sun shading atau menutup atasnya dengan atap.

- Desain harus mendukung kemudahan pejalan kaki dalan berpapasan dengan pengguna lainnya, alternatifnya dengan memberikan pembatas untuk jalur pejalan kaki masuk dan keluar dan untuk jalur kendaraan bermotor

\section{Kepada Pemerintah/Pengelola Mal :}

Rekomendasi yang ditujukan kepada pemerintah/pengelola Mal adalah :

- Perlunya regulasi pemerintah yang jelas terkait tata kelola parkir bagi bangunan publik agar bisa mengakomodir kapasitas kendaraan pengunjung.

- Perlunya regulasi pemerintah yang jelas terkait ruang transisi pada bangunan publik kota yang harus memperhatikan kenyamanan pengguna.

- Bagi pengelola Mall, harus diperhatikan perlunya jalur khusus bagi pejalan kaki yang aman dan perlunya pemisahan jalur kendaraan

\section{Kepada Akademisi}

- Perlu adanya penelitian tentang ruang transisi dengan atribut yang sama namun dengan lokus berbeda sebagai pembanding.

- Perlu adanya penelitian tentang ruang transisi dengan atribut yang berbeda agar dapat saling melengkapi.

Perlu adanya penelitian sejenis dengan metode analisis yang lain sebagai pembanding hasil.

\section{DAFTAR PUSTAKA}

Arikunto, S. (2003). Prosedur Penelitian, Suatu Praktek. Bina AKsara.

Asadi, M. (2015). Introduction To Transition Space In Contemporary Iranian Housing Typology. Journal of Social Sciences and Humanities.

Atkinson, R. L. d. (1983). The Hidden Dimension. Double day.

Boettger, T. (2014). Threshold Spaces Transitions in Architecture Analysis and Design Tools. Birkhäuser Verlag $\mathrm{GmbH}$,

Gerungan, W. . (2000). Psikologi Sosial. Refika Aditama.

Hakim, R. d. H. U. (2003). Komponen Perancangan Arsitektur, Lansekap Prinsip-prinsip dan Aplikasi Desain. Jakarta: Bumi Aksara.

Handayani, K. H., \& Laugu, N. (2007). Studi
Korelasi Motivasi Pengguna Dengan Pemanfaatan Koleksi CD-ROM Di UPT Pusat Perpustakaan UII Yogyakarta. Berkala IImu Perpustakaan Dan Informasi.

Indrosaptono, D. (2011). Persepsi Tempat (Place) Akomodatif Di Kawasan Kota Lama/Bubakan Semarang Sebagai Proses Daur Ulang Sampah Kota (kasus: Sektor Informal Pengelola Sampah Perkotaan). Laporan Akhir Penelitian Pengembangan Teknologi Hibah Bersaing Dana Dipa Fakultas Teknik Universitas Diponegoro.

Marleni, L. (2016). Faktor-Faktor yang Mempengaruhi Minat Belajar Siswa Kelas VIII SMP Negri 1 Bangkinang. Journal Cendekia: Jurnal Pendidikan Matematika, 1(1), 149-159.

Moeliono, dkk. (1989). Kamus Besar Bahasa Indonesia. Balai Pustaka.

Nassar, U. A. (2014). Transition Space in Higher Educational Buildings as an Efficient "Behavior Setting" Model. International Journal of Innovative Research in Science Engineering and Technology (IJIRSET), January. https://www.ijirset.com/upload/2014/janua ry/7_TRANSITION.pdf

Norberg-S̄chulz, C. (1971). Existence, Space \& Architecture. 120.

Singarimbun, M. d. E. S. (1992). Metode Penelitian Survey. Pustaka LP3ES.

Singh, R. (2015). Understanding Transition Spaces. Dissertation, Sushant School of Art and Architecture.

Slameto. (2003). Belajar Dan Faktor-Faktor Yang Mempengaruhinya. Rineka cita.

Subiyantoro, H. (2018). Ruang Transisi Sebagai Pembentuk Estetika Komposisi Ruang. Seminar Nasional Rekayasa Perencanaan VI: Peluang Sarjana Arsitektur Dalam Disain Interior, May 2006.

Sugiyono. (2012). Metode penelitian kuantitatif, kualitatif dan $R$ \& $D$. ALFABETA.

Suharyat, Y. (2009). Hubungan Antara Sikap, Minat, Dan Perilaku. Region, 1(3).

Surasetja, R. I. (2007). Fungsi, ruang, bentuk dan ekspresi dalam arsitektur. Bahan Kuliah, 1-13.

Utami, W. N., Indradjati, P. N., \& Poerbo, H. W. (2018). Kebutuhan Ruang Transisi Di Kawasan Cbd Kota Bandung Berdasarkan Preferensi Dan Persepsi Pejalan Kaki. Tataloka, 20(4), 344. https://doi.org/10.14710/tataloka.20.4.344 $-361$

Wiesmann, J. (1981). Modeling Environmental 
BehaviorSystem. In Journal of Man

Environmental Relation.

Wijaya, C. (2017). Perilaku Organisasi.

Lembaga Peduli Pengembangan

Pendidikan Indonesia (LPPPI). 